\title{
МЕТОДОЛОГІЧНІ ЗАСАДИ ПІЗНАВАЛЬНОЇ ДІЯЛЬНОСТІ В ПРОЦЕСІ ВИКЛАДАННЯ МИСТЕЦЬКИХ ДИСЦИПЛІН
}

\section{Т.Й. Рейзенкінд}

Процеси інтенсифікації професійної підготовки вчителя мистецьких дисциплін необхідно розглядати у контексті організації умов для педагогічного стимулювання особистістю когнітивних смислів як універсального принципу пізнавальної діяльності учнівської молоді. Це потребує розробки та обгрунтування міжпредметних проектів, що об'єднує основи філософських наук, мистецтвознавчих наук та пізнання особливостей мови мистецтва.

На наш погляд, необхідно встановити механізми пізнавальної діяльності на основі рефлексивної установки відносно пізнавальної діяльності, аналізу цієї ситуації у контексті організації конструктивної творчої діяльності у процесі побудови навчальних проектів. Метою нашого дослідження є усвідомлення ролі широкого спектру взаємозв'язків різноманітних форм свідомості, що потребує формування інтегрованих знань, упровадження дослідницьких методів, включення у дослідження соціологічного та гуманітарного фактору.

Виокремлення з метою обгрунтування методологічних засад конструктивних дій у формуванні сучасних знань впливає на формування смислоутворення і дозволяє організовувати проектну діяльність студентів на основі таких загально дидактичних принципів:

1. Добровільність участі в проекті на основі прийняття основних ідей, принципів, змісту і форм організації.

Актуальні проблеми духовності 
2. Свобода вибору проблематики дослідження, певних конструктивних дій на основі сучасних форм мислення.

3. Свобода спілкування на принципах прагнення до взаєморозуміння, взаємотерпимості, конструктивності.

4. Повага до поглядів, ідей, підходів і діяльності учасників форуму $[4$, c. 160$]$.

Методологічними засадами проектної діяльності студентів $є$ організація особистісно-діяльнісного підходу в процесі професійної підготовки вчителя; варіативно-програмний підхід дозволяє самостійно обрати ідеї, норми, цінності у процесі пізнавальної діяльності, забезпечує партнерство, рівноправну співпрацю викладачів та учнівської молоді.

У зв'язку з викладеним, ми наголошуємо на доцільності формування умінь до смислоутворення. Оскільки класифікаційні характеристики принципів базуються на філософській основі і принципи $\epsilon$ тією основою, що забезпечують зміст пізнання за законами наукового мислення, для нашого дослідження необхідно було визначитися у сукупності концепцій, що обгрунтовують формування когнітивних смислів. Ми виходили з того, що доцільно обгрунтування змісту когнітивної стратегії розвитку особистості, структура якої включає аналітичні компоненти щодо наукового знання, процедур його породження, особливості історичного розвитку. Для цього необхідно використовувати оригінальні тексти історії розвитку предмету. Саме ці тексти є дидактичною основою для суб'єкта пізнання [5, с. 22].

$\mathrm{y}$ процесі пізнання дисциплін художньо-естетичного циклу в якості дидактичного матеріалу виступають художні тексти культури та матеріали, створені критиками-філософами, психологами, педагогами, митцями, що займаються аналізом творів мистецтва на основі пізнання художніх творів. До таких матеріалів можна віднести критичні розробки Л. Виготського, Е. Нойманна, К. Юнга, З. Фрейда [7]. Ми виходили з того фактору, що філософський підхід до формування когнітивних смислів дозволяе виокремити ступені форм інтеграції. Перша ступінь передбачає відповідність класичним стандартам, коли механізмамии інтеграції є абстрактно-загальні схеми. На нашу думку, у якості таких схем можуть виступати алгоритми технологічних процедур пізнання інформації на основі комплексного навчання та встановлення міжпредметних зв'язків.

Друга ступень інтеграції дозволяє виконувати функції на основі принципів взаємододатковості та взаємовиключеності, коли зміст на- 
вчання визначається методами, а філософські положення створюють умови для включення у взаємодію цих методів, або дозволяють довести недоцільність організації такої взаємодії [6]. Зазначимо, що майбутній учитель повинен оволодівати методами пізнання за законами митця; саме вивчення художніх текстів культури у взаємодії з критичними текстами є дидактичною основою для діяльності, умови якої забезпечуються формуванням когнітивних смислів, коли визначаються способи та прийоми навчання. При цьому виокремлюються педагогічні ситуації, які впливають на процес досягнення мети пізнання, формування основ сюжетної розбудови наукового знання. Це є ключовою проблемою сьогодення [5].

В.Стьопін у якості вихідного джерела використовує діяльнісний підхід до поставленої проблеми і концентрує увагу на оперуванні ідеальними об'єктами-поняттями, що взаємодіють із конкретно предметними поняттями. При цьому формується новий теоретичний та практичний зміст, коли визначається роль конкретної емпіричної абстракції. Накопичення цих понять передбачає застосування принципу історичної реконструкції. Саме він є механізмом інтеграції між методологічними ідеями та емпіричними абстракціями. Заключні висновки $€$ результатом модифікації аналогічних та часткових суджень. Це забезпечує взаємодію між теоретичними положеннями та досвідом і потребує впровадження взаємодії дедуктивних та індуктивних методів навчання. В. Стьопін пропонує впровадження генетико-конструктивного методу, що передбачає діяльність на основі створення ситуації спостереження, уніфікації спостереження в експерименті та поза експериментом.

О. Карпов протиставляє принципу інституціональності соціального оточення, що базується на «конституюванні» доктринальних груп 3 різноманітними формами засвоєння культури [2, с. 90], принцип науково-інноваційного технологізму, який передбачає подолання «інтегрованого регламентованого комплексу знань, які зумовлені стандартами раціональності» [2, с.95]. Мова йде про забезпечення взаємодії схеми «знання - вчитель - т'ютор - учень». Йдеться про поєднання раціонального та ірраціонального, про включення механізмів інтуїції, що є домінантою у сучасних пізнавальних методах. Метафора трансцендування полягає у синтезі свідомого та безсвідомого. При цьому, на думку автора, формується суб'єктивна інтенція, що передбачає поєднання попереднього пошуку з внутрішньою напругою. Це сприяє дисоціації (порушенню створених раніше уявлень) і породжує нові когнітивні асоціації [2, с.97]. Йдеться про застосування подвійного рефлексивно- 
го механізму «вчитель - т'ютор». Здійснюється форма інтеграції, що включає компоненти класичної шкільної процесуальності у формі науково-орієнтованого навчання. Це сприяє подоланню тенденції формування готових знань, утворенню педагогічних ситуацій для розвитку творчих здібностей.

Водночас нами запозичена ідея впровадження принципу трансцендентності наукового пізнання [6]. Виокремлюються такі ступені інтеграції. Перший ступень пов'язаний з класичними стандартами. Механізмом інтеграції є абстрактно-загальні схеми щодо таких показників як свідомість, психіка; показники ці узагальнюються. Другий ступінь - розвивається парадигма, коли філософія вже виконує функції на основі засад принципів взаємододатковості та взаємовиключення. Зміст дисципліни диктується методом - інтеграція взаємодією методів. При цьому вчитель повинен супроводжувати діяльність учня, що сприяє формуванню особистості на основі реалізації пізнавальної свободи, накопичення духовного досвіду [1, с. 101]. Тобто принцип трансцендентності є першоджерелом, що зумовлює вихід особистості за межі реального «я», у простір духовних почуттів єднання з Богом, у світ неординарних уявлень та фантазії.

Існує варіант моделі метазнання, що базується на когнітивних процесах. Модель метазнання передбачає наявність індивідуальних особливостей особистості. Діяльність когнітивних конструктів на основі інтеграції мистецтв передбачає впровадження стратегій пов'язаних 3 правилами формулювання образів за законами мистецтва. На гальмування цих процесів впливають такі фактори: 1) відсутні загальні терміни реалізації когнітивних процесів; 2) виникають утруднення щодо передачі суб'єкту навчання власних знань, навичок, умінь щодо пізнавальних процесів; 3) немає чіткого визначення засобів управління когнітивними процесами; 4) складно визначити способи ідентифікації різних когнітивних типів суб'єктів; 5) не завжди присутнє розуміння припущень, на яких базуються індивідуальні когнітивні карти суб'єктів, що припускають гнучкість поведінки.

Модель формування метазнань нових смислів $є$ результатом дії нервової системи, що потребує трансляції певних програм. Накопичений досвід є результатом комбінацій чи синтезу інформації, які отримує та переробляє людина. Ці дії забезпечуються органами почуттів. Тобто формування знань здійснюється за допомогою праці мозку та лінгвістичних паттернів. Тобто, в основу покладена стратегія мовного навчання, що враховує необхідність вивчення роботи мозку та особливостей мови, що притаманна кожному тексту культури [1, с.100]. Критері- 
ями визначення особливостей пізнавального процесу $є$ виокремлення мети суб'єкта, аналіз аргументів, що використовує суб'єкт пізнання; вибір альтернатив та відповідно реалізація вчинків; прояв відношення до вирішення завдань. При цьому великого значення набуває фактор оточуючого середовища, поведінки, здібності, що забезпечують вибір стратегії; погляди, що підкріплюють мотивацію; фактори ідентифікації, що визначають характер понадзавдання. Тому ми наголошуємо на доцільності впровадження установки, яка орієнтує на виокремлення актуальності символів. Це має відбиття і у творах мистецтва.

Учитель мистецьких дисциплін повинен мати уявлення про те, що теорія символів не є протиставленням принципу історизму, символічний контекст не знищує матеріальної і специфічної реальності або оточуючого середовища, або художньої реальності. «Символізм забезпечує педагогічне стимулювання, тому що впливає на отримання особистістю додаткових уявлень у процесі формування ціннісного відношення до сприйняття творів мистецтва. Це не може впливати на історичний зміст інформації, що вивчається» [3, с. 10]. Зазначимо, що наукова пізнавальна діяльність ще не формує у свідомості вчителя таку образну модель як множина в єдності. Все пов'язано із взаємодією таких принципів як аналогія та асиміляція, що дозволяє усвідомити суть переходу з однієї форми існування в іншу форму.

У зв'язку з викладеним, можна зробити такі висновки:

1. Формування сучасної особистості вчителя мистецьких дисциплін потребує організації умов у співвідношенні із сучасними методами пізнання. Цьому сприяє децентралізація дій та установок, орієнтованих лише на коло проблем однієї дисципліни. Тому доцільним є пошук механізмів формування знань та понять за законами філософського мислення в умовах посилення інтегративних зв'язків між науковим і художнім пізнанням. Це впливає не лише на визначення етапів когнітивних схем пізнання, але й на змістове наповнення певних етапів дій в процесі пізнавальної діяльності.

2. Кожна епоха культурного становлення особистості характеризується власними особливостями мислення, коли домінуючу роль виконує в процесі обгрунтування теоретичних положень група принципів. Але ці групи принципів поєднуються цілісною стратегією пізнання. У якості такої стратегії виступає підхід, що забезпечує смислоутворення сучасного вчителя. 
3. Проведений дослідницький екскурс дозволяє констатувати коливання між такими філософськими напрямками як логіцистський позитивізм, логіцистський емпіризм, подвійна рефлексія у формуванні когнітивних смислів, технологічно-інноваційний підхід до трансцендування.

Ми вважаємо за доцільне реалізовувати інтеграцію знань на основі подвійної рефлексії, виокремлення фрагментів знань і включення їх у нові взаємозв'язки за допомогою переходу з одного інформаційного поля в інше. Це сприяє виправданню змісту таких понять як «стандарти», «фундаменталізм», «взаємозв'язок раціонального та ірраціонального», дозволяє формувати у вчителя мистецьких дисциплін поліхудожніх знань, умінь та навичок на основі взаємодоповнення принципу історичного підходу до організації навчання.

\section{1 Бібліографія}

[1] Аронов P.A., Баксанский О.Е. Новое в эпистомологии и хорошо забытое старое // Вопросы философии. - 2004. - № 5. - С. 85-110.

[2] Карпов О.А. Принципы научного образования // Вопросы философии. - 2004. - № 11. - С. 89-101.

[3] Керлот Х.Э. Словарь символов. - M.: REFL-book, 1994.

[4] Пехота О.М. Проектна технологія // Освітні технології: Навч.метод. посібник /О.М.Пєхота, А.З. Кіктенко, О.М. Любарська та ін.; За заг. ред. О.М. Пєхоти.- К.: А.С.К., 2001. - С. 148-162.

[5] Cтепин B.C. Важно, чтобы работа не прекращалась // Вопросы философии. - № 9. - С. 16-71.

[6] Философия и интеграция современного гуманитарного знания (материалы «круглого стола») // Вопросы философии. - 2004. № 7. - C. 3-9.

[7] Юнг K., Нойманн Э. Психоанализ и искусство. - M.: REFL-book, Ваклер, 1998. 